Tersedia online di http://ejournal-balitbang.kkp.go.id/index.php/jp
e-mail:jurnalpari@gmail.com
Jurnal Pari
Volume 2 Nomor 1 Juli 2016
p-ISSN : 2502-0730
e-ISSN : 2549-0133

\title{
MONITORING KEGIATAN DISEMINASI HASIL PENELITIAN PADA BALAI PENELITIAN DAN PENGEMBANGAN BUDIDAYA AIR PAYAUTAHUN 2010-2015
}

\author{
Syarianah \\ Balai Penelitian \& Pengembangan Budidaya Air Payau \\ Diterima tanggal : 4 Mei 2016 Diterima setelah perbaikan : 16 Juni 2016 \\ disetujui terbit : 8 Juli 2016
}

\begin{abstract}
ABSTRAK
Kajian ini bertujuan untuk mengevaluasi kegiatan diseminasi informasi teknologi hasil penelitian yang telah dilakukan di Balai Penelitian dan Pengembangan Budidaya Air Payau, Maros. Metode menggunakan analisis dokumen. Hasil Kajian menunjukkan bahwa selama enam tahun (2010 s/d 2015) kegiatan diseminasi iptek budidaya air payau telah dilakukan sebanyak 24 kali. Materi iptek yang disampaikan paling banyak adalah tahun 2010 yaitu sebanyak 17 materi dan paling sedikit tahun 2015 yaitu sebanyak 3 materi. Peserta yang hadir dalam kegiatan diseminasi terdiri dari pembudidaya sebanyak 960 orang, peneliti 229 orang, penyuluh 144 orang, akademisi 37 orang, dan Warga Negara Timur Leste 4 orang. Lokasi pelaksanaan kegiatan diseminasi dilaksanakan di 8 propinsi yaitu Sulawesi Selatan sebanyak 15 kali. Sulawesi Tengah sebanyak 2 kali, Sulawesi Barat, Sulawesi Tenggara, dan Gorontalo masing-maaing 1 kali, Jawa Timur sebanyak 2 kali. Kalimantan Barat dan Kalimantan Selatan masingmasing 1 kali. Dari 62 jumlah materi iptek yang di diseminasikan terdapat lima peringkat yang paling sering adalah Informasi teknologi budidaya rumput laut sebanyak 11 kali, budidaya udang 9 kali, teknologi aplikasi probiotik 8 kali, teknologi kesehatan ikan dan polikultur udang, nilah merah, bandeng dan rumput laut masing-masing 6 kali, dan teknologi budidaya kepiting sebanyak 5 kali. Dari kegiatan diseminasi yang dilakukan diharapkan petani tambak/pembudidaya dapat memanfaatkan teknologi hasil penelitian untuk meningkatkan produksi tambaknya,
\end{abstract}

Kata Kunci : Diseminasi, Monitoring Penelitian, Pengembangan, Budidaya, Air Payau

\section{ABSTRACT}

The aims of the study is to know the total number disseminated information technology resulted from the research conducted by Research Institute for Coastal Aquaculture Maros. The method used is document analysis, result of the study showed that during six years (2010-2015) the dissemination of coastal aquaculture technology was conducted 24 times. The highest number of technology disseminated was found in 2010 with 17 contents of coastal aquaculture technology, while the lowest was obtained in year of 2015 with 3 contents of coastal aquaculture technology. The participants attended the aquaculture dissemination consist of : 960 farmers, 229 researches, 144 extensions, 37 lecturer and 4 foreigner from Timur Leste. Dissemination of aquaculture technology was carried out in eight provinces, namely South Sulawesi 15 events, Central Sulawesi and East Java 2 events, while West and Southeast Sulawesi, Gorontalo, and West and South Kalimantan 1 event. The total number of 62 materials for coastal aquaculture dissemination and ranked to five most frequent dissemination namely: technology of seaweed cultivation 11 times, technology of shrimp culture 9 times, technology of probiotic applications in shrimp culture 8 times, technology of fish healthy and policulture among shrimp, red nile, milkfish and seaweed 6 times and technology of mud crabs culture 5 times. It is expected that the aquaculture technology disseminated were adopted by shrimp/fish farmers and would enhance shrimp/fish production.

Keywords : Dissemination, Monitoring, Research, Coastal Aquaculture

Korespondensi Penulis :

Jl. Makmur Dg. Sitakka No. 129, Maros 90512, Sulawesi Selatan

Email : syariana64@yahoo.co.id 


\section{PENDAHULUAN}

Indikator utama dari penelitian yang sukses adalah bahwa hasil penelitiannya dapat diterapkan, dan bahwa hasil aplikasinya, baik secara langsung atau tidak langsung meningkatkan efisiensi, produktivitas atau keberlanjutan (Garforth, C., 1998). Secara jelas, hasil akhir suatu penelitian harus ada di lahan dan menyebar kepada petani dan nelayan sekitarnya. Oleh karena itu, hasil penelitian harus didiseminasikan kepada "pengguna antara" dan "pengguna akhir teknologi daan informasi. Keberhasilan kegiatan penelitian, tidak terlepas dari tersampaikannya informasi teknologi ke pengguna dengan melalui berbagai media komunikasi. Dalam penyampaian/ penyebar luasan hasil-hasil penelitian, menggunakan berbagai media, antara lain media cetak, seminar, pelatihan atau pertemuan ilmiah, kunjungan, pameran, dan jasa perpustakaan.

Peran peneliti untuk menghasilkan teknologi yang sesuai dengan tuntunan dan kebutuhan akan menjadi strategis ditentukan oleh peran komunikasi penelitian. Analisis diseminasi adalah formulasi informasi yang tergabung dalam sistem makro informasi yang merupakan suatu gambaran tentang mengalirnya informasi yang dapat dipertanggungjawabkan. Diseminasi merupakan hasil dari formula komunikasi menuntut perlu adanya ketepatan berkomunikasi (fidelity of commuication) dalam istilah Berlo (1960). Diseminasi merupakan formulasi komunikasi yang sederhana dimana di dalamnya mencakup unsur-unsur komunikasi. Komunikasi merupakan proses penyampaian pesan dari sumber kepada penerima dengan menggunakan media tertentu yang menimbulkan efek (Onong, 1989). Faktor utama yang dapat mendukung perkembangan suatu kegiatan/praktik dalam suatu keilmuan tertentu adalah di dasarkan dan memanfaatkan hasil-hasil penelitian. Jennet dan Premkumar (1996), mengatakan bahwa setiap riset yang telah dilakukan perlu dipublikasikan dan didiseminasikan. Hasil penelitian akan memperkuat atau mengesampingkan asumsiasumsi yang telah ada sebelumnya dengan informasi yang lebih ilmiah. Manfaat yang paling penting bahwa hasil penelitian tersebut dapat dimanfaatkan sebagai dasar pengambilan keputusan dalam bidang/praktik tertentu (Dobbins Ciliska ,\& Dicenso, 1998).

Balai Penelitian dan Pengembangan Budidaya Air Payau, yang selanjutnya disingkat BPPBAP merupakan Unit Pelaksana Teknis (UPT) Kementerian Kelautan dan Perikanan di bidang penelitian dan pengembangan perikanan budidaya air payau, yang berada di bawah dan bertanggung jawab kepada Kepala Pusat Penelitian dan Pengembangan Perikanan Budidaya. BPPBAP Maros mempunyai tugas pokok dan funsi melaksanakan kegiatan penelitian dan pengembangan strategis perikanan budidaya air payau, melaksanakan penelitian perikanan budidaya air payau di bidang biologi, reproduksi, genetika, bioteknologi, patologi, toksikologi, ekologi, nutrisi dan teknologi pakan, pemetaan dan lingkungan, plasma nutfah dan analisis komoditi. Berdasarkan Peraturan Menteri Kelautan dan Perikanan : Per.32/MEN/2011 tentang Organisasi Dan Tata Kerja Balai Penelitian Dan Pengembangan Budidaya Air Payau bahwa salah satu tugas, fungsi, dan kewenangan adalah pelayanan teknis, jasa, informasi, komunikasi, serta kerja sama penelitian dan pengembangan perikanan budidaya air payau; dimana kegiatan yang dilakukan salah satunya adalah kegiatan diseminasi hasil penelitian dan pengembangan dengan produk kajian berupa diseminasi/bimbingan teknis teknologi perikanan budidaya air payau meliputi bidang kajian: (1) sumber daya budidaya; (2) kesehatan ikan dan lingkungan; (3) nutrisi dan teknologi pakan; (4) bioteknologi; (5) keteknikan budidaya. Masyarakat pengguna teknologi dan informasi hasil penelitian dan pengembangan budidaya air payau meliputi : Pembudidaya, penyuluh, tenaga teknis instansi pemerintah, akademisi, .swasta, dan dinas terkait seperti dinas Kelautan dan Perikanan, Badan Penyuluh Provinsi/ Kab/Kota, dan Perguruan tinggi.

Selama rentang waktu perjalanannya, BPPBAP telah banyak menghasilkan produk penelitian yang inovatif, berupa tersedianya data dan informasi ilmiah, paket teknologi, hasil penelitian dan pengembangan. Temuan IPTEK tersebut perlu dikemas dan disebarluaskan melalui berbagai media sehingga hasil 
penelitian dan pengmbangan tersebut mudah diakses oleh pengguna. Secara umum, publikasi ilmiah merupakan bentuk diseminasi yang biasa dihasilkan oleh institusi atau lembaga penelitian. Namun sesuai dengan ragam pengguna hasil litbang, maka temuan IPTEK perlu dikemas dan disebarluaskan dengan berbagai strategi, bentuk dan media diseminasi, sehingga temuan litbang tidak hanya dinikmati oleh para scientist saja, tetapi juga harus dapat dimanfaatkan oleh berbagai kalangan, baik pemerintah, dunia usaha, dan pembudidaya, nelayan, dam masyarakat luas. Strategi diseminasi perlu dirumuskan bersama antara peneliti (sebagai pihak penemu IPTEK) dan pelayanan teknis (sebagai pihak yang berperan menyediakan rencana dan pelaksanaan kegiatan diseminasi dari temuan IPTEK). Oleh sebab itu, strategi diseminasi perlu dikembangkan secara terstruktur dan inovatif sehingga menimbulkan daya tarik pengguna untuk berinteraksi dan menjalin kerjasama dengan Badan Litbang Kelautan dan Perikanan. Kegiatan diseminasi hasil penelitian dan pengembangan budidaya air payau diharapkan dapat meningkatkan adopsi dan inovasi hasil penelitian dan pengembangan melalui berbagai kegiatan komunikasi, promosi dan komersialisasi serta penyebaran paket teknologi unggul yang dibutuhkan dan menghasilkan nilai tambah khususnya petambak atau pembudidaya serta berbagai khalayak pengguna lainnya.

Kajian ini bertujuan untuk mengevaluasi pelaksanaan kegiatan diseminasi yang telah dilaksanakan oleh Balai Penelitian dan Pengembangan Budidaya Air Payau, Maros selama enam tahun (2010 - 2015). Hal ini dilakukan untuk mengetahui daerah atau wilayah mana saja yang telah dilaksanakan kegiatan diseminasi, informasi atau teknologi hasil penelitian dan pengembangan yang disamapaikan. Jumlah dan jenis peserta yang hadir, serta frekuensi kegiatan diseminasi. Hasil kajian diharapkan dapat menjadi bahan kebijakan dalam penyusunan program dan rencana kegiatan diseminasi selanjutnya.

\section{TINJAUAN PUSTAKA}

Secara etimology kata diseminasi bisa dilihat dalam Merriam Webster Online
Dictionary (2008). Di dalam kamus tersebut dijelaskan bahwa diseminasi berasal dari bahasa Latin disseminatus yang mengandung makna to spread a broad dan to disperse throughout. Pengertian tersebut sejalan dengan istilah dissemination yang juga bermakna to spread atau to distribute (Hornby, 1974; Echols dan Shadily, 1997). Menurut Rachmat Hendayana (2011) Kata diseminasi jarang digunakan dalam percakapan atau penulisan sehari-hari. Kata diseminasi lebih banyak dignakan atau menjadi "jargong" dikalangan akademis (perguruan tinggi), misalnya "diseminasi hasil penelitian" atau dikalangan instansi pemerintah (birokrasi), misalnya " diseminasi hasil penelitian", yakni menyebarkan hasil atau materi pelatihan kepada pegawai karyawan lain. Diseminasi secara khusus diartikan sebagai penyebaran informasi doktrin, pemikiran, kebiajakan, dan hasil penelitian. Ada juga yang mendefinisikan diseminasi sebagai "suatu kegiatan yang ditujukan kepada kelompok target atau individu agar mereka memperoleh informasi, timbul kesadaran menerima dan akhirnya memanfaatkan informasi tersebut".

Menurut Hasan, I. (2014), bahwa Diseminasi adalah suatu kegiatan yang ditujukan kepada kelompok target atau individu agar mereka memperoleh informasi, sehingga timbul kesadaran, menerima, dan akhirnya memanfaatkan informasi tersebut. Istilah umumnya yang digunakan sebagai sinonim dari "penyebaran". Atas dasar pengertian itu dalam kaitannya dengan inovasi teknologi pertanian, diseminasi dapat diartikan sebagai kegiatan penyebarluasan teknologi pertanian spesifik lokasi. Harisetijono, 2014 menyatakan bahwa diseminasi hasil litbang perlu dipandang oleh peneliti dan manajemen Badan Litbang Kehutanan sebagai social responsibility yaitu salah satu langkah pertanggungan gugat atas dana publik yang telah digunakan. Oleh sebab itu, ukuran diseminasi seyogyanya bukan lagi point atau coin (angka kredit atau materi) yang akan didapatkan, tetapi lebih dari itu sebagai bentuk kewajiban sosial yang harus dilaksanakan untuk menyebarluaskan temuan IPTEKnya. Sedangkan menurut Niputu, DK (2013) Diseminasi adalah salah satu kegiatan Balai dalam rangka menyebarluaskan hasil 
rekayasa teknologi budidaya air tawar berupa pelatihan bagi petugas BBI Sentral, BBI, UPR, pembudidaya ikan, dan Pegawai/ Staf teknis perikanan tingkat pusat dan daerah. Kegiatan diseminasi merupakan salah satu kegiatan yang merupakan rangkaian kegiatan BBAT Tatelu yang sebelumnya dimulai dari kegiatan perekayasaan dan uji coba produksi di lapangan. Kegiatan diseminasi teknologi dimaksudkan sebagai upaya menyebarluaskan teknologi hasil-hasil perekayasaan budidaya perikanan kepada masyarakat pengguna, sehingga pada akhirnya diharapkan akan berdampak ke arah peningkatan kemampuan dan peningkatan ekonomi kesejahteraan masyarakat. Selain itu untuk menginformasikan inovasi teknologi kelautan dan perikanan hasil penelitian dan teknologi spesifik lokasi hasil percontohan yang telah direkomendasi.

Secara sederhana, diseminasi digambarkan sebagai proses penyampaian dan penerimaan suatu pesan. Diseminasi adalah proses interaktif mengkomunikasikan pengetahuan kepada khalayak target, sehingga dapat digunakan untuk melakukan perubahan. Analisis diseminasi adalah formulasi informasi yang tergabung dalam sistem makro informasi yang merupakan suatu gambaran tentang mengalirnya informasi yang dapat dipertanggungjawabkan. Diseminasi merupakan hasil dan formulasi komunikasi menuntut perlu adanya ketepatan berkomunikasi (Berlo, 1960). Aswel dalam Onong 1977, menyatakan bahwa diseminasi merupakan formulasi komunikasi yang sederhana, yang didalamnya mencakup unsurunsur komunikasi, sedangkan komunikasi dalam hal ini merupakan proses penyampaian pesan dari sumber kepada penerima dengan menggunakan media tertentu yang menimbulkan efek. Dalam hal ini ada lima unsur dalam proses komunikasi adalah komunikator, komunikan, pesan, media dan efek. Diseminasi teknologi sebagai salah satu prioritas program utama yang dilaksanak an secara konsisten dengan melibatkan sumberdaya yang ada.

Diseminasi bertujuan untuk mempercepat penerimaan suatu pesan yang mudah dipahami oleh pengguna (pengguna antara dan pengguna akhir) tentang suatu informasi baru. Pengguna akhir adalah petani yang terlibat langsung dalam proses produksi tanaman pangan. Sedangkan pengguna antara adalah peneliti, komunikator, swasta, lembaga penyuluhan, dan pembuat kebijakan, yang memproses informasi menjadi produk akhir untuk diaplikasikan oleh pengguna akhir Rachmat, H. (2011). Dalam penyampain dan penyebarluasan itu tersirat adanya harapan atau respon terhadap materi yang disebarluaskan itu. Jadi diseminasi harus merupakan proses penyampaian inovasi yang interaktif, dapat merubah pola pikir dan tindakan orang yang terlibat di dalamnya, termasuk orang yang membawa inovasi itu sendiri (Rogers, 1983). Dalam kegiatan penelitian, diseminasi dapat dipandang sebagai sebuah proses mengkomunikasikan teknologi hasil penelitian menggunakan beberapa metode penyuluhan melalui media dan bersifat lebih luas dengan tujuan untuk mengubah perilaku sasaran. Perubahan yang diharapkan dari kegiatan diseminasi adalah akan terjadi pada aspek kognitif (pengetahuan - P), afektif (sikap - S) dan psikomotorik (keterampilan - K). Perubahan tersebut menuju ke arah yang sesuai dengan konsep dan cara yang benar atau seharusnya.

\section{BAHAN DAN METODE}

Pengkajian dilaksanakan, pada bulan Februari-Maret 2016, di Balai Penelitian dan Pengembangan Budidaya Air Payau, Maros melalui analisis dokumen dan wawancara. Analisis dokumen dilakukan dengan cara pencatatan dan perhitungan secara sistematis terhadap unit kajian yang akan dibahas. Data tersebut merupakan data yang berasal dari hasil laporan kegiatan diseminasi yang dibuat setiap tahun oleh bagian pelayanan teknis. Sedangkan wawancara dilakukan dengan pihak pelaksana kegiatan diseminasi dalam hal ini bagian pelayanan teknis dan narasumber materi dalam hal ini peneliti BPPBAP. Hasil pengkajian diungkapkan secara deskriptif untuk memberikan gambaran tentang pelaksanaan kegiatan diseminasi yang telah dilakukan yang meliputi :

1. Kegiatan Deiseminasi BPPBAP dalam kurung waktu 6 tahun (2010 sampai 2015) 


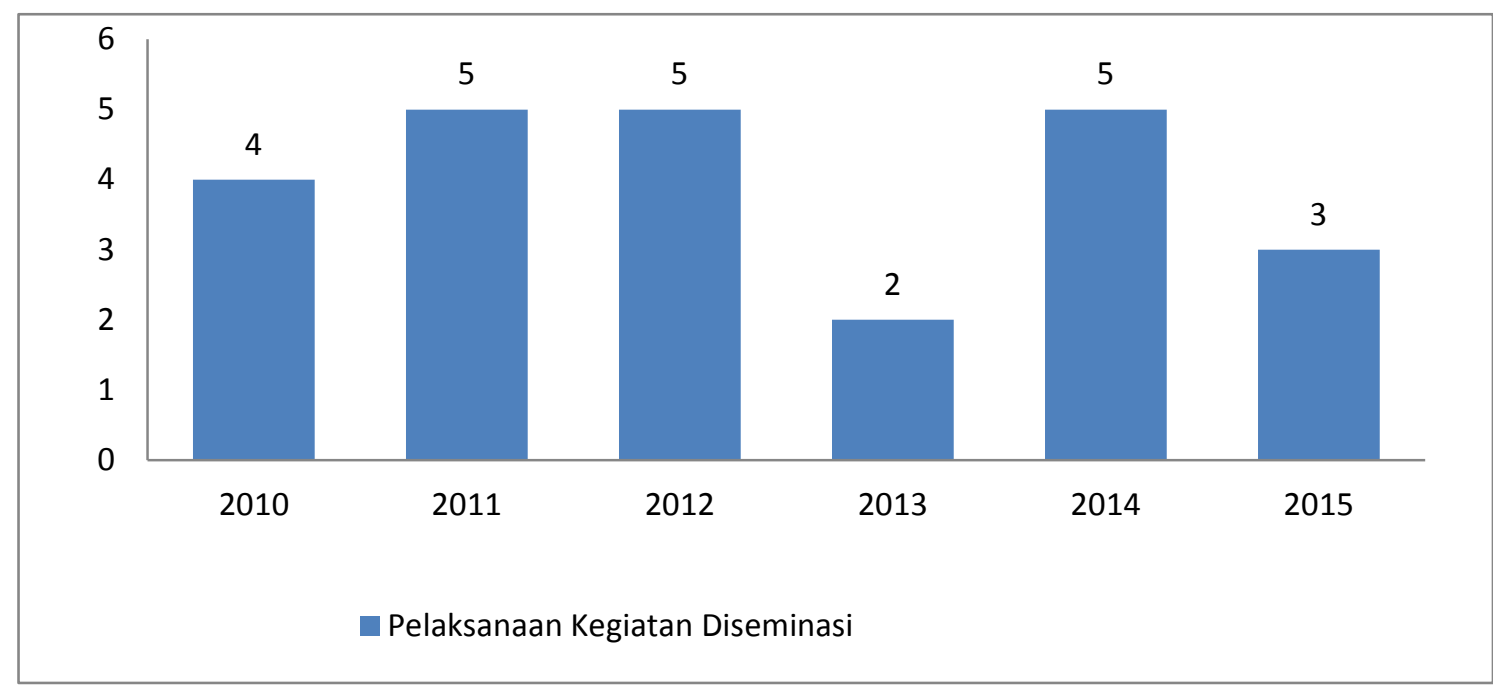

Gambar 1. Kegiatan Diseminasi BPPBAP selama 6 tahun (2010 s/d 2015)

2. Informasi teknologi hasil litbang yang disampaikan dalam kegiatan diseminasi

3. Peserta yang hadir pada kegiatan diseminasi

4. Pelaksanaan kegiatan diseminasi berdasarkan lokasi

5. Teknolog informasi hasil litbang yang paling sering di diseminasikan

\section{PEMBAHASAN}

Keberhasilan kegiatan penelitian dan pengembangan, tidak terlepas dari tersampaikannya informasi teknologi ke pengguna dengan melalui berbagai media komunikasi. Dalam penyampaian/penyebar luasan hasil-hasil penelitian dan pengembangan, Balai Penelitian dan Pengembangan Budidaya Air Payau, Maros menggunakan berbagai media, antara lain media cetak, seminar, diseminasi, pelatihan atau pertemuan ilmiah/temu lapang, kunjungan, pameran, dan jasa perpustakaan. Selama 6 tahun terakhir dari tahun 2010 sampai dengan tahun 2015 telah dilakukan kegatan penyebaran dan diseminasi hasil penelitian ke petani tambak, pembudidaya, nelayan dan stak holder melalui Temu Lapang, Peragaan teknologi dan informasi, dan Komunisasi tatap muka.

Selama enam tahun dari tahun 2010 sampai tahun 2015 BPPBAP, Maros telah melakukan kegiatan diseminasi sebanyak 24 kali. Dari Gambar 1 terlihat bahwa pelaksanaan kegiatan diseminasi pada tahun 2011, 2012, dan 2014 yaitu sebanyak lima kali. Pada tahun 2010 empat kali, tahun 2015 tiga kali, dan pada tahun 2013 hanya dua kali. Hal ini menunjukkan adanya ketidak tetapan jumlah pelaksanaan kegiatan deseminasi setiap tahunnya. Ini disebabkan karena dalam menetapkan pelaksanaan kegiatan diseminasi dipengaruhi oleh adanya permintaan dari Dinas Kelautan dan Perikanan atau Kelompok Tani di daerah serta adanya ketersediaan dana.

Diseminasi merupakan upaya yang sangat penting bagi Lembaga Penelitian dan Pengembangan dalam penyebarluasan dan komersialisasi hasil-hasil penelitian. Bentuk, jenis, dan strategi diseminasi perlu dirumuskan sesuai dengan target sasaran diseminasi. Harisetijono 2014, mengemukakan bahwa langkah-langkah penting yang diperlukan untuk meningkatkan upaya diseminasi, antara lain : mengidentifikasi ketersediaan dan status hasil litbang sesuai dengan tujuan diseminasi, memetakan target sasaran diseminasi, mengidentifikasi sarana dan media diseminasi sesuai dengan target sasaran dan kondisi wilayah, meningkatkan kualitas sarana media diseminasi, termasuk penyiapan bahan materi, dan penyempurnaan layanan teknologi informasi, meningkatkan jejaring kerja pada tataran institusi dan tataran praktis.

Jumlah informasi teknologi (Iptek) yang disampaikan dalam kegiatan diseminasi bervariasi setiap tahunnya. Pada Gambar 2 terlihat bahwa penyajian materi iptek paling banyak yaitu pada tahun 2010 yakni sebanyak 
17 iptek. Sedangkan paling sedikit pada tahun pembangunan?, d). Apakah hasil penelitian dan 2015 hanya 3 iptek. Dari data tersebut pengembangan mampu berkompetisi dengan

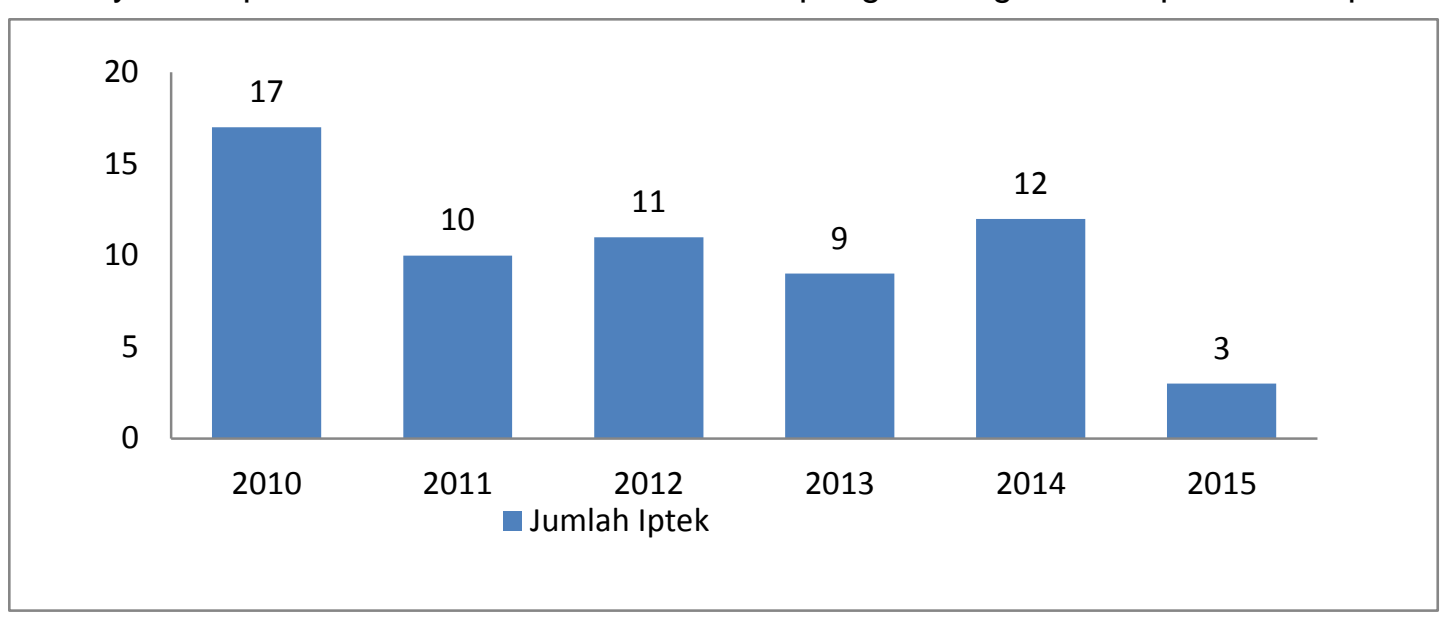

Gambar 2. Jumlah Informasi Teknologi yang disampaikan dalam pelaksanaan kegiatan diseminasi

menunjukkan bahwa ada menurunan jumlah materi iptek selama enam tahun. Hal ini disebabkan karena jenis kegatan diseminasi yang dilakukan berkaitan dengan banyaknya kegiatan penelitian dan pengembangan yang dilakukan oleh balai pada tahun berjalan.

Diseminasi hasil litbang terkait dengan institusi atau lembaga riset lainnya? (Harisetijono 2014).

Lebih lanjut dijelaskan bahwa upaya peningkatan diseminasi dilakukan dengan penentuan strategi diseminasi yang tepat akan mempercepat proses penyerapan inovasi IPTEK yang disebarluaskan. Hal penting yang

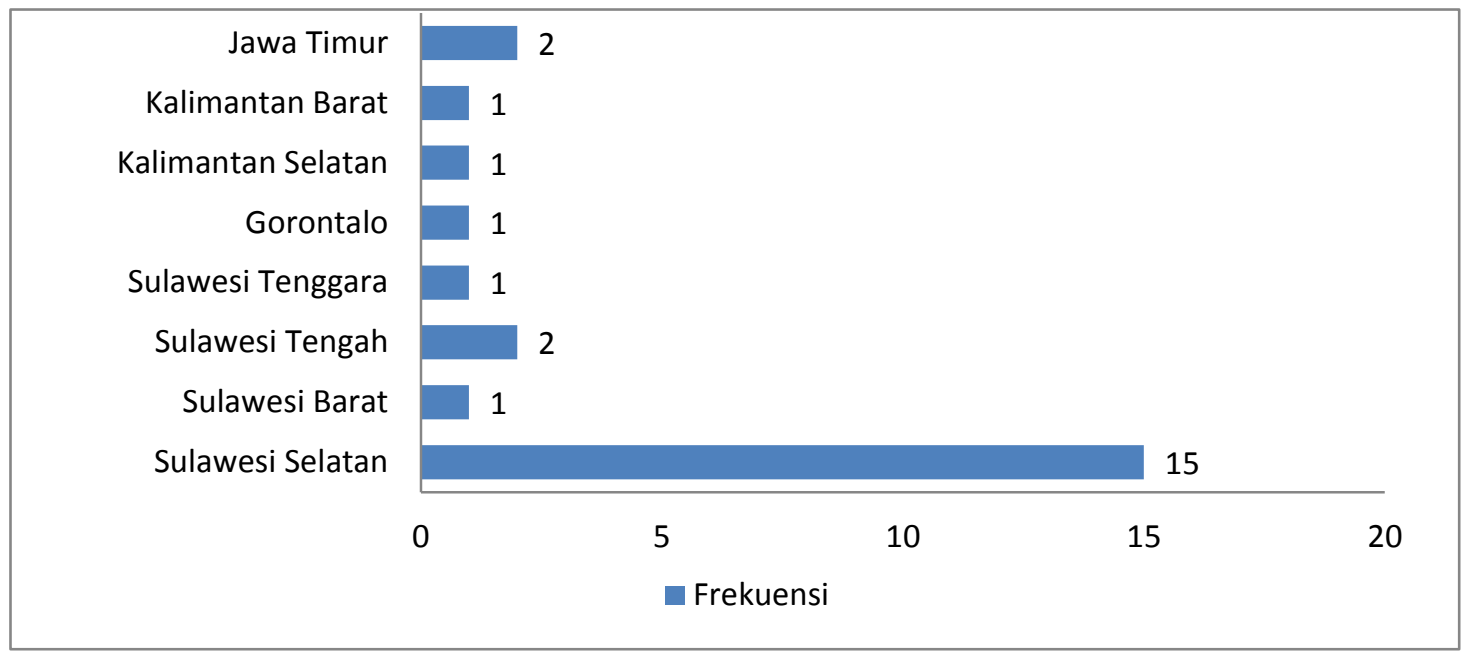

Gambar 3. Kegiatan Diseminasi BPPBAP berdasarkan Frekuensi dan Lokasi

ketersediaan dan status IPTEK. Lebih lanjut dikemukakan bahwa beberapa hal penting yang perlu diperhatikan dalam upaya peningkatan diseminasi, antara lain a). Apakah IPTEK yang dihasilkan sudah tepat sasaran, tepat waktu, dan sesuai dengan kebutuhan pengguna, b). Sejauh mana kesiapan hasil litbang untuk mendukung diseminasi pada setiap target sasaran, c). Apakah hasil litbang dapat diintegrasikan dalam kemasan paket IPTEK untuk menjawab pemecahan masalah dalam menjadi pendorong dan sekaligus peluang untuk untuk meningkatkan upaya diseminasi adalah suatu kenyataan bahwa penggunaan IPTEK sangat diperlukan untuk menunjang pelaksanaan kebijakan dan efektifitas pengambilan keputusan suatu kebijakan. Tanpa harus memperdebatkan antara kesesuaian hasil riset dalam pemenuhan kebutuhan dukungan IPTEK dalam pembangunan, nampaknya temuan IPTEK perlu dipilah dan dipilih sesuai target sasaran 
sehingga diseminasi dapat mengakomodasikan kebutuhan pengguna.

Dari dua puluh empat kali pelaksanaan kegiatan diseminasi oleh BPPBAP Maros, sebanyak 15 kali diadakan di Propinsi Sulawesi Selatan yaitu Kabupaten Maros dan Pangkep masing-masing 4 kali, Kabupaten Barru dan Luwu masing-masing 2 kali, dan Kabupaten Bulukumba, Pinrang, dan Sinjai masing-masing 1 kali. Propinsi Sulawesi Tengah diadakan 2 kali yaitu di Kabupaten Parigi dan Konawe Selatan. Sedangkan Pelaksanaan kegiatan diseminasi di Propinsi Sulawesi Barat dan Sulawesi Tenggara dilakukan masing-masing 1 kali yaitu di Kabupaten Mamuju dan Kota Kendari. Di Propinsi Gorontalo dilakukan kegiatan diseminasi sebanyak 1 kali yaitu di Kota Gorontalo (Gambar 3).

Jumlah peserta yang mengikuti kegiatan diseminasi BPPBAP selama kurun waktu enam tahun berjumlah 1.508 orang. Pada Gambar 4, menunjukkan bahwa peserta yang paling banyak mengikuti kegiatan diseminasi adalah pembudidaya yaitu sebanyak 960 orang atau 64\%. Hal tersebut merupakan target utama dari BPPBAP, Maros untuk dapat mensosialisasikan dan menerapkan iptek hasil keuntungan usahanya, Target kedua adalah penyuluh kelautan dan perikanan, karena kelompok ini merupakan tenaga pendamping bagi pembudidaya di lapangan dalam pelaksanaan kegiatan usahanya. Meskipun dari data diatas menunjukkan bahwa kelompok penyuluh menduduki posisi peringkat ketiga dari besarnya jumlah peserta, yang hadir yaitu sebanyak 144 orang atau $10 \%$ dari total peserta. Dari tabel tersebut di atas memperlihatkan bahwa peserta dari instansi terkait juga hadir sebanyak 134 orang atau sebesar $9 \%$, hal ini menunjukkan adanya perhatian dari pemerintah terutama pemerintah setempat terhadap pelaksanaan kegiatan diseminasi. Selain itu peserta dari akademisi juga hadir yaitu sebanyak 37 orang atau $2 \%$.

Dan yang tidak kalah pentingnya adalah peserta dari Warga Negara Timur Leste sebanyak 4 orang $(0.3 \%)$ yang khusus datang untuk belajar bagaimana cara membudidayakan kepiting.

Menurut Harisetijono 2014, Pemetaan target sasaran diperlukan sebagai upaya "menemukenali" kelompok dan kebutuhan pengguna IPTEK. Masing-masing kelompok pengguna akan menentukan bentuk, kemasan, cara dan media diseminasi yang digunakan. Secara umum, target sasaran pengguna dapat

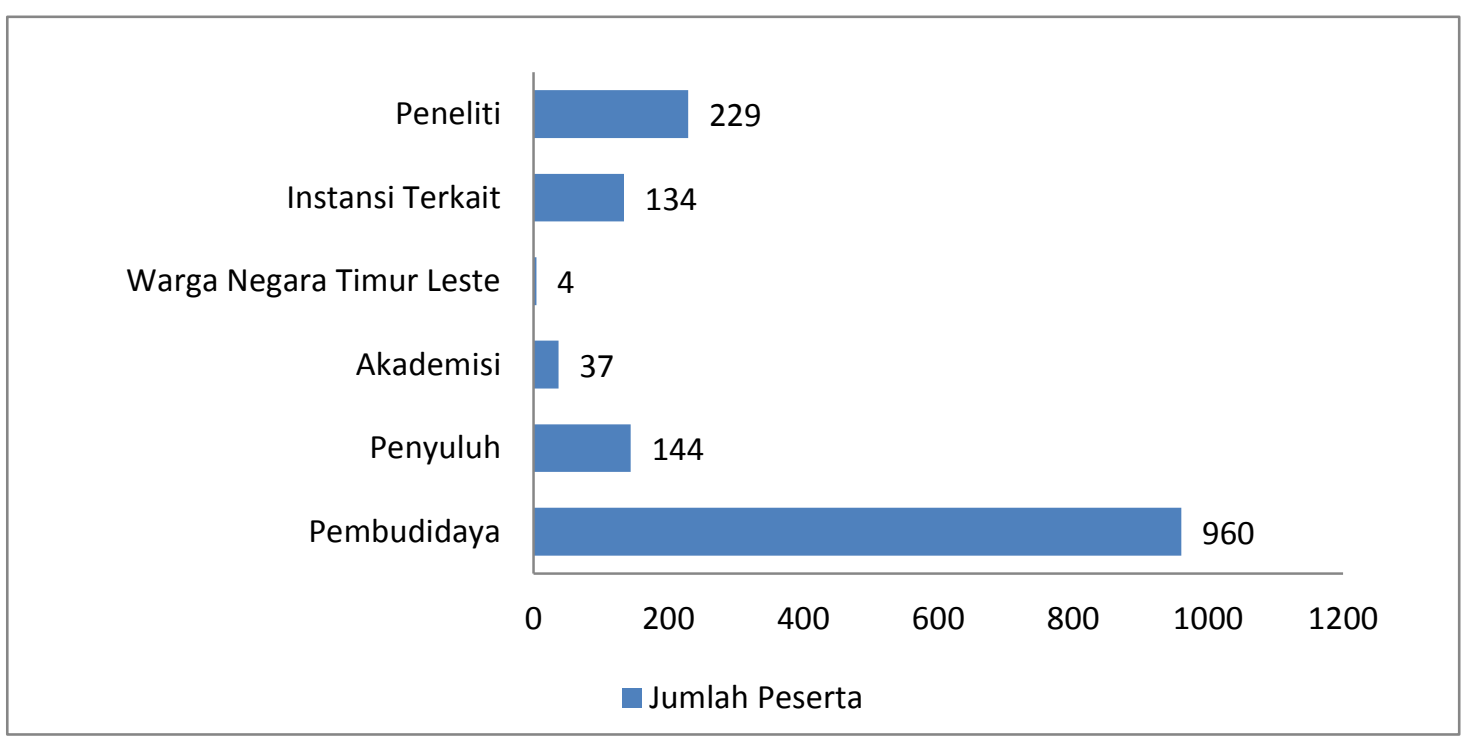

Gambar 4. Peserta Kegiatan Diseminasi BPPBAP selama 6 tahun, 2010 s/d 2015

penelitian dan pengembangan yang telah dihasilkan. Karena pembudidaya merupakan kelompok pelaku yang memanfaatkan iptek hasil litbang budidaya yang mampu meningkatkan produktifitas, pengembangan dan dikelompokkan menjadi:

a. Kelompok Scientist, yaitu kelompok pengguna yang umumnya lebih berorientasi pada pengembangan 
khasanah ilmu pengertahuan dan teknolo gi.

b. Kelompok pelaku usaha, yaitu kelompok pengguna yang umumnya lebih menekankan pada IPTEK yang mampu meningkatkan produktifitas, pengembangan dan keuntungan usaha.

c. Masyarakat umum, yaitu kelompok pengguna yang memiliki ragam kepentingan yang bervariasi sesuai dengan tingkat pengetahuan, kemauan dan kemampuan mengadopsi inovasi teknologi, pemenuhan kebutuhan hidup dan pengembangan usaha skala mikro.

d. Pemerintah, yaitu kelompok pengguna yang umumnya berorientasi pada penggunaan IPTEK sebagai bahan pengambilan kebijakan publik.

Dari enam puluh dua jumlah materi iptek yang disampaikan dalam kegiatan diseminasi terdapat lima peringkat yang frekuensi penyampaian paling sering (Gambar 5). Dari data tersebut menyajikan bahwa teknologi budidaya rumput laut yang paling sering di diseminasikan yaitu sebanyak 11 kali. teknologi budidaya udang 9 kali, teknologi aplikasi iptek dalam kegiatan diseminasi selain di tentukan berdasarkan kegiatan penelitian yang dilaksanakan dilokasi tersebut, juga ditentukan oleh permintaan dari Dinas Kementerian dan Kelautan atau kelompok tani. Sehingga materi iptek yang dsampaikan betul betul sesuai dengan kebutuhan pembudidaya dan kelompoknya.

\section{KESIMPULAN DAN SARAN}

Untuk menyebarluaskan hasil penelitian dan pengembangan BPPBAP maros melakukan kegiatan diseminasi. Dalam kurung waktu enam tahun yaitu tahun 2010 sampai dengan tahun 2015 telah dilakukan kegiatan diseminasi sebanyak 24 kali, di 8 propinsi yang meliputi 15 kabupaten dan kota.

Materi yang disampaikan sebanyak 62 iptek dengan jumlah peserta 1.508 orang terdiri dari petani tambak/pembudidaya, peneliti, penyuluh, instansi terkait, akademisi, dan warga negara Timur Leste. Materi iptek yang paling sering didiseminasikan adalah teknolog budidaya rumput laut, teknologi budidaya udang, teknologi aplikasi probiotik, teknologi kesehatan

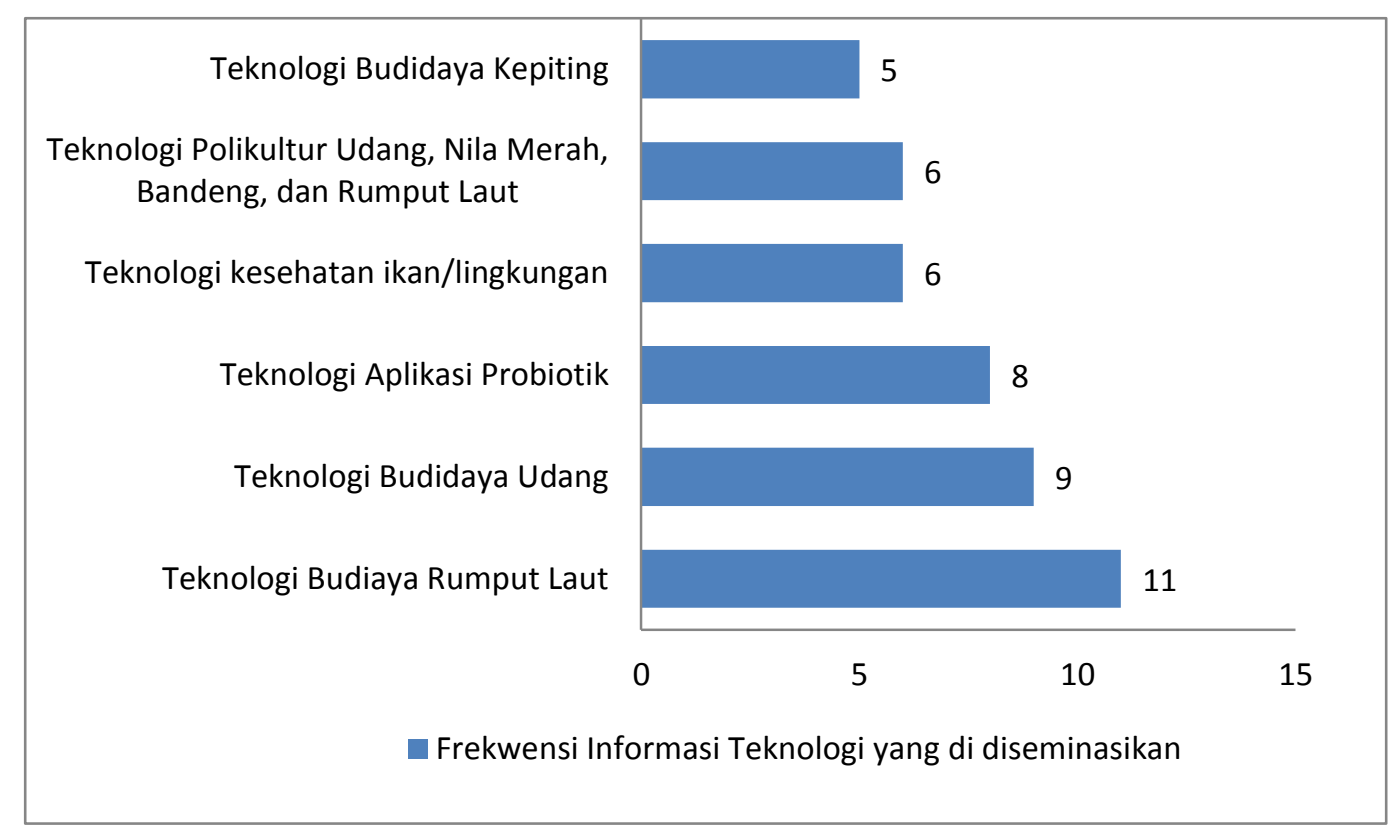

Gambar 5. Informasi Teknologi yang disampaikan pada Kegiatan Diseminasi

probiotik 8 kali, teknologi kesehatan ikan/lingkungan dan teknologi polikultur udang, nila merah, bandeng dan rumput laut masingmasing 6 kali. Sedangkan teknologi budidaya kepiting 5 kali. Penentuan materi ikan/lingkungan, teknologi polikultur udang, nila merah, bandeng dan rumput laut, serta teknologi budidaya kepiting.

Sebagaimana tugas dan fungsinya yang bersekala nasional, maka BPPBAP Maros 
diharapkan dapat melakukan kegiatan diseminasi diseluruh wilayah Indonesia terutama daerah-daerah yang memiliki tambak budidaya air payau. Sehingga seluruh petani tambak atau pembudidaya mampu mengembangkan dan meningkatkan produktifitas dan keuntungan usaha budidayanya. Perlu dilakukan kajian lebih lanjut untuk mengetahui sejauhmana aplikasi teknologi budidaya ini diterapkan oleh pembudidaya dan bagaimana pengaruhnya terhadap peningkatan produksi usahanya.

\section{DAFTAR PUSTAKA}

Anonim.

Diseminasi. Dalam http://www.wikiapbn.org/artikel/Disemina si, tanggal 12 April 2012.

Dobbins, M.; Ciliska, M.; DiCenso, D.: Dissemination and use of research evidence for policy and practice: a framework for de-veloping, implementing, and evaluating strategies. A report pre-pared for the Dissemination and Utilization Model Advisory Committee of the Canadian Nurses Association and Health. Canadian Nurses Association, Canada, 1998.

Berlo. 1960. Planning for in inovation Through Disemination an Utilitizen of Knowlage. The University of Macigan, un arbur Micigan.

Garforth, C., 1998. . Dissemination pathways for RNR research. Socio-economic Methodologies. Best Practice Guidelines. Chatham, UK: Natural Resources Institute.

Hasan, Ali. 2014. Marketing dan Kasus-Kasus Pilihan. Buku I, Cetakan Kedua. Penerbit CAPS, Yogyakarta.

Harisetijono. Diseminasi Hasil Litbang : Langkah Penting Untuk Penyebarluasan Hasil Litbang . Warta Matoa, Vol. 1 No. 1,2014 .

Hornby, A.S. 1974; Oxford Advanced Learner's Dictionary Of Current English, London: Oxford University Press

Jennet, P. A., \& Premkumar, K. (1996). Technology-based dissemination. Canadian Journal of Public Health 87 (6)
Merriam-Webster. 2012. http://www.merriamwebster.com/dictionary/dissemination tanggal 13 April 2012

Miriam, Siti. 2008. Efektivitas Diseminasi Teknologi Pertanian Melalui Perpustakaan Digital (Kasus pada Pusat Perpustakaan dan Penyebaran Teknologi Pertanian) dalam JURNAL Penelitian dan Pengembangan Komunikasi dan Informatika. Jakarta: Departemen Komunikasi dan Informatika.

Niputu, DK. 2013. Diseminasi Teknologi Budidaya Ikan Air Tawar. dalam Kelautan dan Perikanan, Penyuluhan Perikanan, Juli 2013

Onong, L.E, 1977. Ilmu Komunikasi Teori dan Praktek. PT Remaja Rosdakarya, Bandung.

Rachmat Hendayana. Diseminasi Multi Channel. Apa itu diseminasi? (diposted Januari 2011). https://diseminasi.wordpress.com/2011/ 01/04/halo-dunia/

Rogers, E. M. (1983). Diffusion of Innovations. New York. A Devision of Macmillan Publishing Co. Inc.

Septian, Tya. 2010. Skripsi: Peran Pusat Perpustakaan Dan Penyebaran Teknologi Pertanian (PUSTAKA) Dalam Penyebaran Informasi Hasil Penelitian Badan Litbang Pertanian Melalui Pemanfaatan Jaringan Informasi . Jakarta: Universitas Indonesia. 